\title{
Comparison of codon usage in mycobacteriophages with and without tRNAs in their genomes
}

\author{
Ethan S Gill ${ }^{1}$, Claire A Rinehart ${ }^{2 *}$ \\ From 12th Annual UT-ORNL-KBRIN Bioinformatics Summit 2013 \\ Buchanan, TN, USA. 22-24 March 2013
}

\section{Background}

Mycobacterium smegmatis is a soil bacterium. Over 448 mycobacteriophages specific for $M$. smegmatis have been sequenced and grouped into clusters of related genomes based on the similarity of their products and genome organization [1]. Eighty-one of these sequenced phage genomes contain at least one tRNA.

\section{Materials and methods}

In this study we compared the codon frequencies between the phages that carry tRNA in their genome (Clusters A2, A3, A5, A6, A9, C1, C2, E, J, K1, L1, L2, $\mathrm{M})$ to those phages without tRNA in their genome (Clusters A1, A4, B1, B2, D, F1, G) in order to determine whether the tRNAs being carried by the mycobacteriophages were needed to survive in M. smegmatis. The phages with embedded tRNAs were drawn from http:// phagesdb.org/data/. The coding sequences for the mycobacteriophages were obtained from NCBI GenBank [2]. Codon frequencies were derived for each mycobacteriophage and a BoxWhiskerChart (Figure 1) was made using a program written in Mathematica ${ }^{B}$.

To determine which codons may require expression of phage tRNAs, Figure 1 plot regions for phages containing tRNA (red) that show frequencies in excess of those not containing tRNA (blue) have been circled in magenta. Only a few codons meet this criteria: ACT, ATG, CAG*\%, CGT, GAC $*$, GAG*, TAC, TAT, TGG. A significant number of mycobacteriophages lay outside the non-tRNA phage boundaries for codons CAG, GAC

\footnotetext{
* Correspondence: claire.rinehart@wku.edu

${ }^{2}$ Department of Biology, Western Kentucky University, Bowling Green, KY, 42101, USA

Full list of author information is available at the end of the article
}

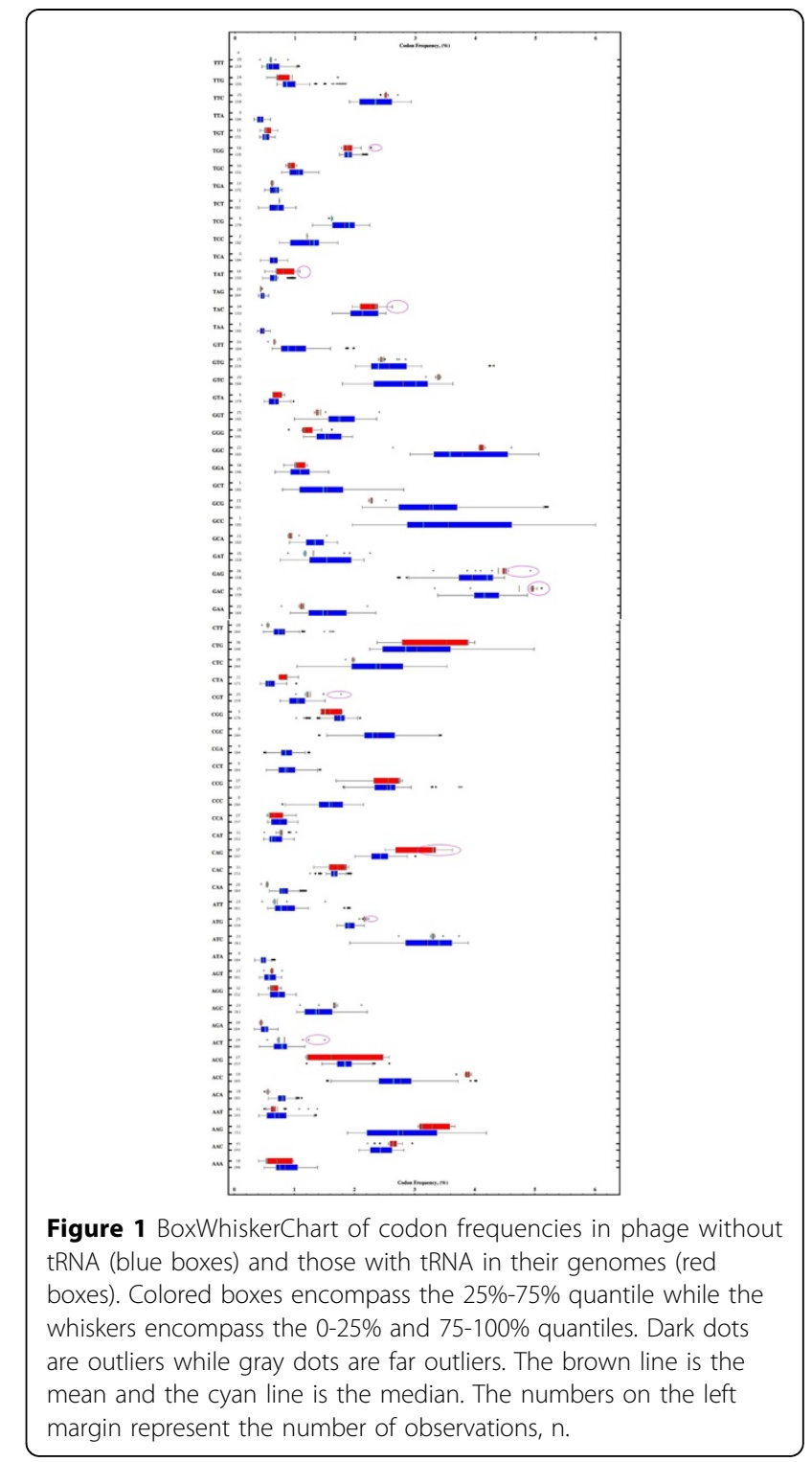


and GAG, therefore, these phages may be dependent on internally coded tRNAs.

\section{Authors' details}

${ }^{1}$ Department of Computer Science, Western Kentucky University, Bowling Green, KY, 42101, USA. '2Department of Biology, Western Kentucky University, Bowling Green, KY, 42101, USA.

Published: 22 October 2013

\section{References}

1. Hatfull GF: Mycobacteriophages: genes and genomes. Annu Rev Microbiol 2010, 64:331-356.

2. Benson DA, Karsch-Mizrachi I, Clark K, Lipman DJ, Ostel J, Sayers EW: GenBank. Nucleic Acids Res 2012, 40(Database issue):D48-D53.

doi:10.1186/1471-2105-14-S17-A9

Cite this article as: Gill and Rinehart: Comparison of codon usage in mycobacteriophages with and without tRNAs in their genomes. BMC Bioinformatics 2013 14(Suppl 17):A9.

Submit your next manuscript to BioMed Central and take full advantage of:

- Convenient online submission

- Thorough peer review

- No space constraints or color figure charges

- Immediate publication on acceptance

- Inclusion in PubMed, CAS, Scopus and Google Scholar

- Research which is freely available for redistribution

Submit your manuscript at www.biomedcentral.com/submit
() Biomed Central 